\title{
ROLE OF CALMODULIN IN STATES OF ALTERED CATECHOLAMINE SENSITIVITY
}

\author{
M. E. Gnegy, Y. S. Lau, and G. Treisman \\ Department of Pharmacology \\ University of Michigan Medical School \\ Ann Arbor, Michigan 48109
}

\section{INTRODUCTION}

Calmodulin, an endogenous calcium-binding protein, can modulate the intracellular concentration of adenosine $3^{\prime}, 5^{\prime}$-cyclic monophosphate (cyclic AMP) by stimulating membrane-bound adenylate cyclase activity and soluble phosphodiesterase (PDE) activity.' There is increasing evidence that calmodulin can modulate the effects of calcium at both pre-and postsynaptic sites in some areas of brain. Calmodulin is enriched in rat brain synaptic membranes ${ }^{2}$ and has been located in postsynaptic densities in mouse basal ganglia ${ }^{3}$ and canine cerebral cortex. ${ }^{4}$ Previous studies have suggested that calmodulin is involved with dopamine (DA)-sensitive adenylate cyclase activity in rat striatum. Gnegy et $a l^{5}$ found that depletion of calmodulin from striatal membranes results in a decreased ability of DA to stimulate adenylate cyclase activity. Furthermore, the calmodulin content in the striatum was increased under conditions of dopamine supersensitivity. ${ }^{6}$ Rats treated chronically with cataleptogenic antipsychotic drugs and then withdrawn from the drugs had increased calmodulin content in their striatal membranes. These animals exhibited behavioral supersensitivity to apomorphine and their striatal adenylate cyclase had an increased affinity for dopamine as demonstrated by a 3- to 4-fold increase in dopamine sensitivity. The increase in calmodulin could positively affect DA-sensitive adenylate cyclase activity and thus contribute to dopaminergic: supersensitivity.

The increased calmodulin in the striatal membranes of the supersensitive rats seems to be more tightly bound to its membrane binding proteins. ${ }^{7}$ In the brain, calmodulin can be bound to membrane proteins in a calcium-dependent and calcium-independent manner. ${ }^{k}$ Calmodulin has been shown to bind to $\mathrm{Ca}^{2+}$ dependent $\mathrm{PDE}^{9}$ and $\mathrm{Ca}^{2+}$-sensitive adenylate cyclase ${ }^{10}$ as well as other proteins. Vandermeers et al. ${ }^{11}$ have demonstrated a correlation between increased $\left[{ }^{125} \mathrm{I}\right]$ calmodulin binding and activation of adenylate cyclase activity in guinea pig membranes.

In this work we investigate more directly whether calmodulin can affect DA-sensitive activity in rat striatal membranes. We found that calmodulin could affect both the maximal velocity of the reaction and the sensitivity to DA. We studied the binding of calmodulin to striatal membranes in order to further investigate the relationship between calmodulin interaction with adenylate cyclase activity. We showed specific binding of $\left[{ }^{125} \mathrm{I}\right]$ calmodulin to striatal membranes that was competitively inhibited by trifluoperazine, an antipsychotic drug that binds to calmodulin and inhibits its action. ${ }^{12}$ We have also shown that the ability of the calmodulin content to increase could be specific for dopaminergic supersensitivity in the striatum. 


\section{METHODS \\ Membrane Preparation}

Striatal membranes were depleted of calmodulin by a modification of the method of Brostrom et al..$^{13}$ Male, Sprague-Dawley rats $(150-200$ g) were sacrificed by decapitation; the striata were removed and homogenized in $9 \mathrm{vol}$ of 10 $\mathrm{mM}$ Tris-maleate buffer, $\mathrm{pH} 7.5$, containing $1 \mathrm{mM} \mathrm{MgSO}_{4}, 1.2 \mathrm{mM}$ EGTA, and 10 $\mu \mathrm{M}$ guanosine triphosphate (GTP). The homogenate was centrifuged at $27,000 \times \mathrm{g}$ for $20 \mathrm{~min}$, resuspended in the same buffer, and centrifuged a second time at $27,000 \times \mathrm{g}$. The pellet resulting from the final centrifugation was resuspended in $10 \mathrm{mM}$ Tris-maleate buffer, $\mathrm{pH} 7.5$, containing $1.2 \mathrm{mM}$ EGTA and $1 \mathrm{mM} \mathrm{MgSO}_{4}$.

\section{Adenylate Cyclase Assay}

Adenylate cyclase activity was measured in an assay $[200 \mu \mathrm{l}$ vol] containing: $80 \mathrm{mM}$ Tris-maleate buffer, pH 7.5; $5 \mathrm{mM} \mathrm{MgSO}_{4} ; 2 \mathrm{mM}$ cyclic AMP, $4 \mathrm{mM}$ phosphoenolpyruvate, $20 \mu \mathrm{g}$ pyruvate kinase, $0.12 \mathrm{mM}$ isobutylmethylxanthine, 100-150 $\mu \mathrm{g}$ membrane protein, $0.15 \mathrm{mM}$ EGTA (carried over from the membrane preparation), $1 \mathrm{mM}$ [alpha $\left.{ }^{32} \mathrm{P}\right]$ ATP $\left(1-2 \times 10^{6} \mathrm{cpm} /\right.$ assay $)$, with or without additions, such as, $10 \mu \mathrm{M}$ guanyl-5'-yl-imidodiphosphate (Gpp(NH)p), $10 \mu \mathrm{M}$ GTP, $125 \mu \mathrm{M} \mathrm{CaCl}_{2}$, and $500 \mathrm{ng}$ ( $28 \mathrm{pmol}$ ) of highly purified calmodulin prepared from bovine brain according to Klee. ${ }^{14}$ Assays were incubated for $3 \mathrm{~min}$, stopped by heating $1 \mathrm{~min}$ at $95^{\circ} \mathrm{C}$, and $200 \mu \mathrm{l}$ of a solution containing $20 \mathrm{mM}$ ATP and 0.7 $\mathrm{mM}$ cyclic AMP was added to the tubes. The membranes were centrifuged, and the $\left.{ }^{32} \mathrm{P}\right]$-cyclic AMP in the supernatant was determined by the method of Krishna et al. ${ }^{15}$ Recovery of the cyclic AMP was measured using $\left[{ }^{3} \mathrm{H}\right]$-cyclic AMP and was $65-70 \%$.

\section{Determination of Calmodulin Content}

Calmodulin was assayed by its ability to stimulate calmodulin-deficient PDE activity ${ }^{9}$ in the PDE assay described previously. ${ }^{2}$ The calmodulin content in nanograms was determined from a standard curve using highly purified calmodulin.

\section{Binding Assay}

Calmodulin was iodinated using $\left.{ }^{125} \mathrm{I}\right] \mathrm{N}$-succinimidyl-3-(4-hydroxyphenol) propionate (Bolton-Hunter reagent, Amersham) as described by Chafouleas et $a l^{16}$ and had a specific radioactivity of $428 \mathrm{Ci} / \mathrm{mmol}$. Calmodulin binding studies were performed as described by Vandermeers et al.$^{10}$ with some modifications. The assay medium (in final volume of $0.2 \mathrm{ml}$ ) contained $80 \mathrm{mM}$ Tris-maleate buffer, pH 7.5, $5 \mathrm{mM} \mathrm{MgSO}_{4}, 0.2 \%$ bovine serum albumin, and various testing agents as indicated. Calmodulin ( $\left({ }^{125}\right.$ I-labeled and non-labeled) was added to each assay so that the specific activity remained constant at $8 \mathrm{nCi} / \mathrm{pmol}$ of calmodulin. The reaction was initiated by the addition of the calcium- and calmodulindepleted striatal membrane preparation $[60-80 \mu \mathrm{g}$ protein] and the reaction 
mixture was incubated at $37^{\circ} \mathrm{C}$ for 2 minutes, unless otherwise indicated. To terminate the reaction, the sample was diluted with $2 \mathrm{ml}$ of the ice-cold incubation buffer and filtered immediately under vacuum through a EHWP 0.5 $\mu \mathrm{m}$ Millipore filter (Millipore Co., Bedford, Mass.) that had been prewashed with the buffer. The filters were rapidly washed twice with $2 \mathrm{ml}$ of the same ice-cold buffer, dried, and counted in an Auto-gamma scintillation counter (Packard Model 5220). The nonspecific binding, determined by adding a 100 -fold excess of nonlabeled calmodulin to the assay showed no significant difference from the assay blank (without membrane). Both the blank and the nonspecific binding represented less than $0.7 \%$ of the total radioactivity. Trifluoperazine, when used, was preincubated in the medium for 20 minutes at $37^{\circ} \mathrm{C}$ before the membranes were added.

\section{Membrane Calcium Determination}

Striatal membrane calcium content was measured using the method as described by Schmidt and Way ${ }^{17}$ with some modifications. An aliquot $(0.5 \mathrm{ml})$ of membrane fractions (4-5 mg protein) was treated with $0.5 \mathrm{ml}$ of $10 \%$ trichloroacetic acid (TCA). The mixture was equilibrated for 30 minutes and centrifuged at $5,000 \times \mathrm{g}$ for 15 minutes. The pellet was used to determine protein content ${ }^{18}$ while the clear supernatant of the sample was mixed with $1 \mathrm{ml}$ of $1 \% \mathrm{La}^{3+}$ in $5 \%$ $\mathrm{HCl}$. Sample blanks and standards were similarly treated. Calcium concentrations were assayed using an atomic absorption spectrophotometer (Varian Model AA 375]. Four readings per sample were taken and averaged. The limit of detection by this spectrophotometric method was $5 \mathrm{nmol}$ calcium $/ 0.5 \mathrm{ml}$ sample.

The free calcium concentration reported in the binding studies was calculated according to Nanninga and Kempen ${ }^{19}$ where the concentrations of EGTA and $\mathrm{Mg}^{2+}$ and the buffer $\mathrm{pH}$ were taken into consideration. All data were calculated in terms of mean \pm S.E.M. Statistical analysis was performed using the $t$ test either for unpaired or for paired comparison whenever appropriate. A $\mathrm{P}<\mathbf{0 . 0 5}$ was considered significant.

\section{RESULTS}

\section{Effect of Calmodulin and Calcium on Basal Adenylate Cyclase Activity}

Depletion of most of the calmodulin content from the striatal membranes was necessary to observe the stimulatory effects of this protein on adenylate cyclase

TABLE 1

Calmodulin Content, Calcium Content, and adenylate Cyclase activity in Rat Striatal Membranes Before and after EGTA Treatment

\begin{tabular}{|c|c|c|c|}
\hline Conditions & $\begin{array}{l}\text { Membrane } \\
\text { Calmodulin } \\
\text { Content } \\
\text { ( } \mu \mathrm{g} / \mathrm{mg} \text { protein })\end{array}$ & $\begin{array}{c}\text { Membrane } \\
\text { Calcium } \\
\text { Content } \\
\text { [nmol/mg protein] }\end{array}$ & $\begin{array}{c}\text { Adenylate } \\
\text { Cyclase } \\
\text { Activity } \\
\text { (pmol/min } / \mathrm{mg} \text { protein) }\end{array}$ \\
\hline Buffer & $4.9 \pm 0.6(3)$ & $12.3 \pm 0.8(5)$ & $175 \pm 7(3)$ \\
\hline Buffer + EGTA & $2.9 \pm 0.3(3)$ & not detectable (10) & $105 \pm 17(3)$ \\
\hline
\end{tabular}


TABLE 2

Effect of Calcium and Calmodulin on Basal adenylate Cyclase Activity in Rat StRiatal, MEMBRanes

\begin{tabular}{ccc}
\hline $\begin{array}{c}\text { Calcium added } \\
\text { to Assay } \\
(\mu \mathrm{M})\end{array}$ & \multicolumn{2}{c}{$\begin{array}{c}\text { Adenylate Cyclase Activity } \\
(\mathrm{pmol} / \mathrm{min} / \mathrm{mg} \text { protein } \pm \text { S.E.M. })\end{array}$} \\
\cline { 2 - 3 } & - Calmodulin & + Calmodulin \\
\hline $\mathbf{5 0}$ & $96 \pm 6(4)$ & $76 \pm 11(4)$ \\
100 & $97 \pm \mathbf{1 2}$ & $78 \pm 10$ \\
125 & $94 \pm \mathbf{1 6}$ & $135 \pm \mathbf{8}$ \\
200 & $86 \pm 10$ & $145 \pm 18$ \\
\hline
\end{tabular}

activity. The EGTA treatment depleted most, but not all, of the calmodulin from the membrane fraction. As shown in TABLE 1, the calmodulin content in the membranes was depleted by $41 \%$ after EGTA treatment. Originally, nearly $50 \%$ of the calmodulin content in the brain cell is located in the membranes. EGTA washing similarly decreased the specific activity of the basal adenylate cyclase activity in the membrane fraction by $41 \%$ (TABLE 1). The calcium content in EGTA-washed membranes was below the level of detection.

Neither calcium nor calmodulin individually were able to stimulate basal adenylate cyclase activity in the striatum. Calcium itself did not really affect basal activity until high concentrations were added $(>200 \mu \mathrm{M})$. Calmodulin and calcium added together had a biphasic action on adenylate cyclase activity (TABLE 2). In the presence of $500 \mathrm{ng}$ of calmodulin $\left(1.4 \times 10^{-7} \mathrm{M}\right)$, concentrations of calcium added between $50 \mu \mathrm{M}$ and $150 \mu \mathrm{M}$ elicited stimulation of adenylate cyclase activity with a maximum effect at $125 \mu \mathrm{M}$ calcium. Adenylate cyclase activity was inhibited at concentrations of calcium of less than $50 \mu \mathrm{M}$ or greater than $200 \mu \mathrm{M}$ in the presence of calmodulin. The effective concentrations of calcium providing stimulation was actually very low because the assay contained $150 \mu \mathrm{M}$ EGTA. Using a $K_{\mathrm{D}}$ for Ca-EGTA calculated according to Nanninga and Kempen, ${ }^{19}$ addition of $125 \mu \mathrm{M}$ calcium will result in an effective concentration of $0.14 \mu \mathrm{M}$ calcium.

As shown in FIGURE 1, guanyl nucleotides were able to produce a greater maximal stimulation of adenylate cyclase than did calmodulin. $10 \mu \mathrm{M} \mathrm{Gpp}(\mathrm{NH}) \mathrm{p}$ stimulated the adenylate cyclase activity by $200 \%$. Calcium significantly inhibited the Gpp(NH)p-stimulated adenylate cyclase activity by $60 \%$. Addition of calmodulin reversed the calcium inhibition with the result that the stimulation by $\mathrm{Gpp}(\mathrm{NH}) \mathrm{p}$, calcium, and calmodulin was the same as that of $\mathrm{Gpp}(\mathrm{NH}) \mathrm{p}$ alone. The interaction of calcium and calmodulin with GTP stimulation of basal activity qualitatively differed from that observed with Gpp(NH)p. GTP-stimulated adenylate cyclase activity was slightly stimulated by both calcium and calmodulin. Calcium will inhibit GTP-stimulated adenylate cyclase activity but much greater concentrations of calcium are required $(200 \mu \mathrm{M}$ added calcium, which is $>2 \mu \mathrm{M}$ effective calcium). Stimulation of adenylate cyclase activity by calmodulin was specific because troponin $\mathrm{C}$, calcium-binding protein from muscle, did not stimulate basal adenylate cyclase activity even at 10-fold higher concentrations. Furthermore, troponin $\mathrm{C}$ did not reverse the effects of calcium on $\mathrm{Gpp}(\mathrm{NH}) \mathrm{p}$ stimulation as did calmodulin. 


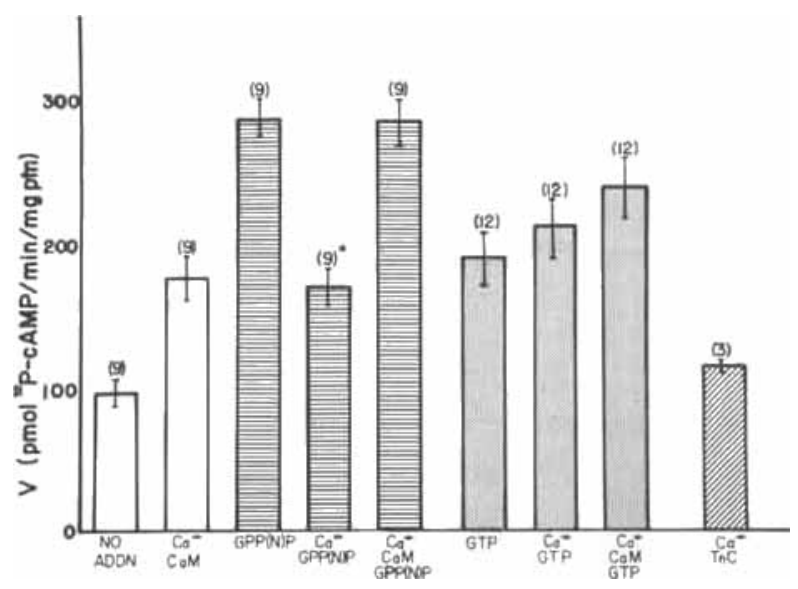

FIGURE 1. Stimulation of adenylate cyclase activity in rat striatum by calmodulin and guanyl nucleotides. Adenylate cyclase assays were performed as described in METHODS with the following additions: $10 \mu \mathrm{M}$ Gpp(NH)p [GPP(N)P] or GTP; $500 \mathrm{ng}$ of calmodulin (CaM) or $125 \mu \mathrm{M} \mathrm{CaCl}_{2}$. The number of experiments is given in parentheses. ${ }^{\star} \mathrm{P}<0.01$ as compared to the value for $\mathrm{Gpp}(\mathrm{NH}) \mathrm{p}$, alone.

\section{Effect of Calmodulin on DA-Sensitive Adenylate Cyclase Activity}

Adenylate cyclase activity in striatal membranes that had been washed repeatedly with EGTA could not be stimulated by DA. Addition of calcium, calmodulin, or both agents together was insufficient to restore DA sensitivity. Inclusion of $10 \mu \mathrm{M} \mathrm{Gpp(NH)p} \mathrm{or} \mathrm{GTP} \mathrm{in} \mathrm{the} \mathrm{assay} \mathrm{was} \mathrm{necessary} \mathrm{to} \mathrm{achieve} \mathrm{a}$ dose-dependent response to DA in the formation of cyclic AMP. Adenylate cyclase activity was stimulated 1.4-1.5 fold by DA in the presence of $10 \mu \mathrm{M}$ $\mathrm{Gpp}(\mathrm{NH}) \mathrm{p}$. This actually represented a large stimulation over the original basal activity (TABLE 1). The increase in adenylate cyclase activity in the presence of 10 $\mu \mathrm{M} \mathrm{Gpp}(\mathrm{NH}) \mathrm{p}$ reached a maximum at $5 \mu \mathrm{M}$ DA. The $K_{\text {att }}$ for DA in the presence of $\mathrm{Gpp}(\mathrm{NH})$ p was $1.1 \mu \mathrm{M}$ and the $V_{\max }$ was $100 \mathrm{pmol} / \mathrm{min} / \mathrm{mg}$ protein (TABLE 3). Addition of $125 \mu \mathrm{M}$ calcium brought about a $50 \%$ decrease in $V_{\max }$ with no

\section{TABLE 3}

Kinetic Constants for Stimulation of Striatal Dopamine-Sensitive Adenylate Cyclase by Gpp(nh)p. Calcium, and Calmodulin

\begin{tabular}{ccc}
\hline \multicolumn{1}{c}{$\begin{array}{c}\text { Additions to } \\
\text { Assay }\end{array}$} & $\begin{array}{c}K_{\text {act }} \\
(\mu \mathrm{M} \pm \text { S.E.M.) }\end{array}$ & $\begin{array}{c}V_{\text {max }} \\
\text { (pmol/min/mg protein } \pm \text { S.E.M.) }\end{array}$ \\
\hline $\mathrm{Gpp}(\mathrm{NH}) \mathrm{p}$ & $1.1 \pm 0.2$ & $100 \pm 15$ \\
$\mathrm{Gpp}(\mathrm{NH}) \mathrm{p}+\mathrm{Ca}^{2+}(5)$ & $0.83 \pm 0.1$ & $45 \pm 5^{\star *}$ \\
$\begin{array}{c}\mathrm{Gpp}(\mathrm{NH}) \mathrm{p}+\mathrm{Ca}^{2+}(5) \\
+ \text { calmodulin }\end{array}$ & $0.56 \pm 0.1^{*}$ & $77 \pm 12$ \\
\hline
\end{tabular}

* $\mathrm{P}<0.005$ as compared to value with $\mathrm{Gpp}(\mathrm{NH}) \mathrm{p}$ alone or $\mathrm{Gpp}(\mathrm{NH}) \mathrm{p}+\mathrm{Ca}^{2+}$.

${ }^{*} \mathrm{P}<0.02$ as compared to value with $\mathrm{Gpp}(\mathrm{NH}) \mathrm{p}$ alone or $\mathrm{Gpp}(\mathrm{NH}) \mathrm{p}+\mathrm{Ca}^{2+}+$ calmodulin. 
TABLE 4

Kinetic Constants for Stimulation of Striatal Dopamine-Sensitive Adenylate Gyclase activity in the PResence of GTP, Calcium and Calmodulin

\begin{tabular}{ccc}
\hline \hline $\begin{array}{c}\text { Additions to } \\
\text { Assay }\end{array}$ & $\begin{array}{c}K_{\text {act }} \\
(\mu \mathrm{M} \pm \text { S.E.M. })\end{array}$ & $\begin{array}{c}V_{\max } \\
(\mathrm{pmol} / \mathrm{min} / \mathrm{mg} \text { protein } \pm \text { S.E.M.) }\end{array}$ \\
\hline GTP $\quad(8)$ & $3.8 \pm 0.7$ & $122 \pm 9$ \\
GTP $+\mathrm{Ca}^{2+}(5)$ & $5.2 \pm \mathbf{0 . 1}$ & $68 \pm 8^{\star *}$ \\
GTP $+\mathrm{Ca}^{2+}(8)$ & & $112 \pm 10$ \\
+ Calmodulin & $1.8 \pm 0.4^{*}$ & $112 \pm 0$ \\
\hline \hline
\end{tabular}

${ }^{\star} \mathrm{P}<0.04$ as compared to value with GTP alone or GTP $+\mathrm{Ca}^{2+}$.

${ }^{\star *} \mathrm{P}<0.001$ as compared to value with GTP alone or GTP $+\mathrm{Ca}^{2+}+$ calmodulin.

change in sensitivity for DA. When $500 \mathrm{ng}$ of calmodulin was added with the calcium, the maximal velocity was restored to $80 \%$ of the value found with $\mathrm{Gpp}(\mathrm{NH}) \mathrm{p}$ alone and the dose response curve for DA was shifted in a parallel manner to the left. The $K_{\text {act }}$ for DA was decreased 2-fold to $0.56 \mu \mathrm{M}$ (TABLE 3). The average kinetic parameters of 5 separate experiments for DA stimulation of adenylate cyclase in the presence of $\mathrm{Gpp}(\mathrm{NH}) \mathrm{p}$ are shown in TABLE 3.

The same pattern was seen for the effects of calcium and calmodulin on DA-stimulated activity in the presence of $10 \mu \mathrm{M}$ GTP. Adenylate cyclase activity was stimulated 1.7-1.8 fold by DA in the presence of $10 \mu \mathrm{M}$ GTP. The $K_{\text {act }}$ for DA stimulation of adenylate cyclase was $3.8 \mu \mathrm{M}$ (TABLE 4), nearly 3 times greater than that found in the presence of $\mathrm{Gpp}(\mathrm{NH}) \mathrm{p}$. The $V_{\max }$ of the reaction $(122 \mathrm{pmol} /$ $\mathrm{min} / \mathrm{mg}$ protein) was slightly greater, however, than that obtained with $\mathrm{Gpp}(\mathrm{NH})$. Addition of $125 \mu \mathrm{M}$ calcium to the assay again decreased DA stimulation, in spite of the fact that calcium did not decrease GTP stimulation of

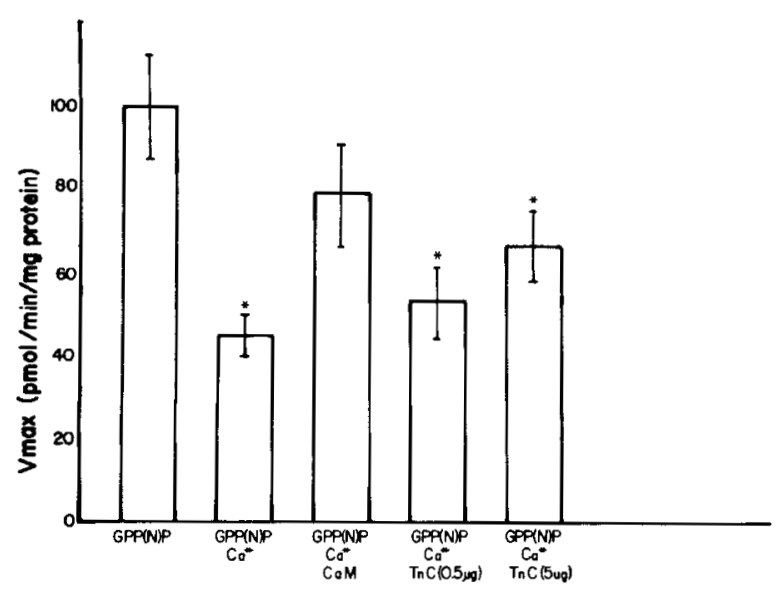

FIGURE 2. Effect of troponin $\mathrm{C}$ on maximal velocity of dopamine-sensitive adenylate cyclase activity in rat striatum. The $V_{\max }$ of the dopamine-sensitive adenylate cyclase reaction was calculated from Lineweaver Burk plots from 3 different experiments. Concentrations of additions are: $10 \mu \mathrm{M} \mathrm{Gpp}(\mathrm{NH}) \mathrm{p}(\mathrm{GPP}(\mathrm{N}) \mathrm{P}), 500 \mathrm{ng}$ calmodulin $(\mathrm{CaM}), 500 \mathrm{ng}$ or 5 $\mu \mathrm{g}$ troponin $\mathrm{C}$ (TnC), or $125 \mu \mathrm{M} \mathrm{CaCl}_{2}$. ${ }^{*} \mathrm{P}<0.05$ as compared to the value for $\mathrm{Gpp}(\mathrm{NH}) \mathrm{p}$ alone. 
basal activity. In this case calcium reduced the $V_{\max } 2$-fold with no significant change in the $K_{\text {act }}$ for DA. Addition of calmodulin with the calcium elicited an increase in $V_{\max }$ to the level found with GTP alone and resulted in a 2 -fold sensitivity for DA $\left(K_{\text {act }}\right.$ for DA $\left.=1.8 \mu \mathrm{M}\right)$. Kinetic constants for DA-stimulation of adenylate cyclase in the presence of GTP for 8 different experiments are shown in TABLE 4.

The effect of calmodulin on DA-sensitive adenylate cyclase activity was specific for calmodulin in the capacity of a calcium-binding protein. Troponin $\mathrm{C}$ could not completely substitute for the effects of calmodulin on the maximal velocity of DA-stimulated activity even at nearly 10-fold higher concentration than calmodulin (FIGURE 3). The molecular weight of troponin $C$ is 17,800 daltons. ${ }^{20}$ Troponin $\mathrm{C}$ did not increase the affinity for DA.

\section{Binding of $f^{225}$ I Calmodulin to Striatal Membranes}

Although the experiments using troponin $\mathrm{C}$ indicated a specific interaction of calmodulin with adenylate cyclase, we wished to show that calmodulin was able to bind specifically to striatal membranes under the conditions of the adenylate cyclase assay. Therefore, we developed an assay to measure the binding of $\left[{ }^{125} \mathrm{I}\right] \mathrm{calmodulin}$ to striatal membranes depleted of calcium and calmodulin. The dependence of calmodulin binding upon time and temperature was determined in the presence of $1.25 \times 10^{-4} \mathrm{M}$ added calcium $(0.14 \mu \mathrm{M})$ in membranes previously depleted of calcium and calmodulin. Binding of $\left[{ }^{125} \mathrm{I}\right]$ calmodulin was

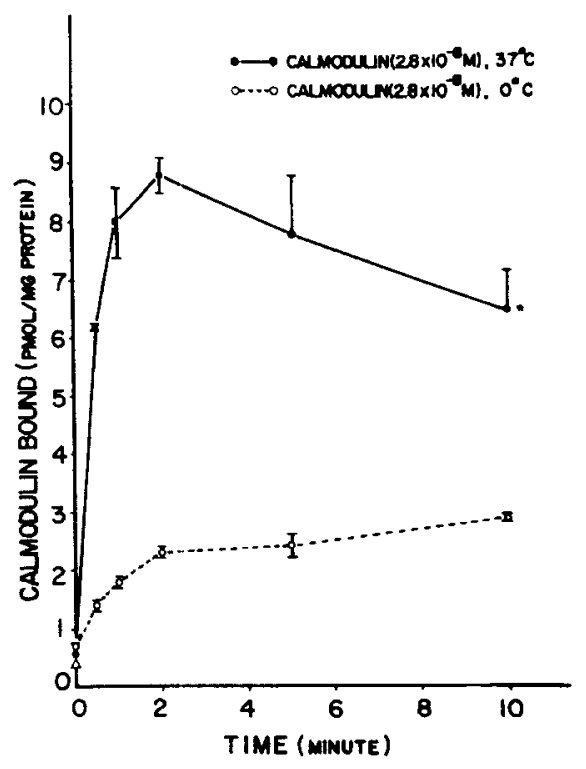

Figure 3. Effects of time and temperature on $\left[{ }^{125} \mathrm{I}\right] \mathrm{calmodulin}$ binding in rat striatal membranes. The membranes were depleted of calcium and calmodulin as described in the MEthods. The assays contained $1.25 \times 10^{-4} \mathrm{M} \mathrm{CaCl}_{2}$. "Value significantly lower than the peak binding response at $2 \mathrm{~min} . N=4$. 




FIGURE 4. Effect of calcium on $\left[{ }^{125} I\right] c a l m o d u l i n$ binding in rat striatal membranes. Free calcium concentrations in the assay were calculated according to Nanninga and Kempen. ${ }^{19}$ The assays were incubated at $37^{\circ} \mathrm{C}$ for 2 minutes. $N=3$. *Significantly different from the value when no calcium was added.

found to be rapid and maximal binding was reached after 2 minutes of incubation. However, the binding decreased when incubation was continued at $37^{\circ} \mathrm{C}$ (FIGURE 3). The extent of calmodulin binding was markedly decreased when incubation was performed at $0^{\circ} \mathrm{C}$ (FIGURE 3) but the time-dependent decrease was not seen. A protease could be destroying the calmodulin at the higher temperature.

Calmodulin binding to calcium- and calmodulin-depleted membranes was dependent on the concentration of calcium added into the assay. Calmodulin binding was substantially enhanced by increasing concentrations of calcium (FIgURE 4). $1.25 \times 10^{-4} \mathrm{M}$ calcium $\left(1.4 \times 10^{-7} \mathrm{M}\right.$ calculated free $\mathrm{Ca}^{2+}$ ) exhibited a maximal binding of calmodulin to the membranes, while calcium less than $10^{-5}$ $\mathrm{M}\left(2 \times 10^{-9} \mathrm{M}\right.$ free $\left.\mathrm{Ca}^{2+}\right)$ did not affect the binding significantly, as compared to the binding with no calcium added (FIGURE 4).

Calmodulin binding to the striatal membranes was saturable; saturation being reached at $500 \mathrm{ng}$ of calmodulin $\left(1.4 \times 10^{-7} \mathrm{M}\right)$ in the presence of $1.25 \times 10^{-4} \mathrm{M}$ calcium. Trifluoperazine $\left(10^{-4} \mathrm{M}\right)$ produced a significant shift of the control calmodulin-binding to the right (FIGURE 5). In four experiments, trifluoperazine at $10^{-5} \mathrm{M}$ did not antagonize calmodulin binding significantly and at $10^{-3} \mathrm{M}$ the drug did not produce further inhibition of calmodulin binding than at $10^{-4} \mathrm{M}$ (data not shown].

The above results (FIGURE 5) were plotted according to the Scatchard analysis. Saturation of binding occurred with a maximal number of binding sites of $11.8 \pm$ $1.2 \mathrm{pmol} / \mathrm{mg}$ protein (determined by extrapolation from 11 experiments) (TABLE 5). The Scatchard plot, as well as the displacement curve, suggests that there are 


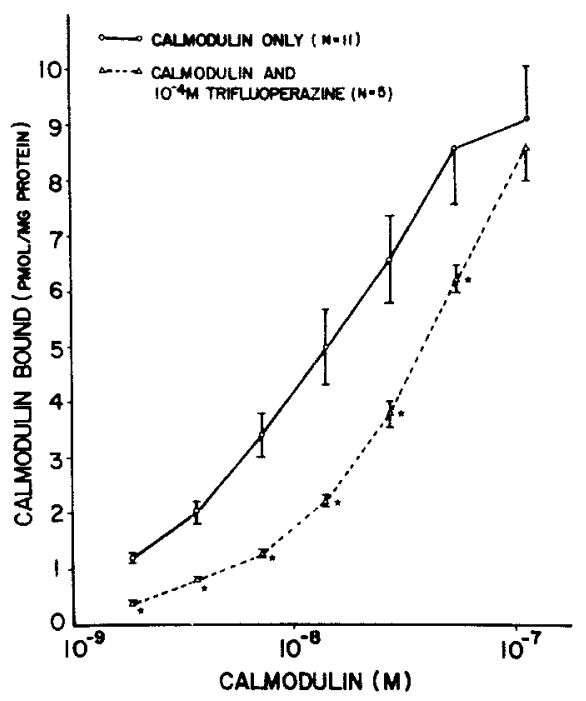

FIGURE 5. Effect of trifluoperazine $\left(10^{-4} \mathrm{M}\right)$ on the dose-response curve of $\left[{ }^{125} \mathrm{I}\right] \mathrm{calmodu}$ lin binding in rat striatal membranes. Trifluoperazine was preincubated for 20 minutes at $37^{\circ} \mathrm{C}$ in the presence of $1.25 \times 10^{-4} \mathrm{M} \mathrm{CaCl}_{2}$ before the membranes were added. The binding reaction was carried out at $37^{\circ} \mathrm{C}$ for 2 minutes. ${ }^{*}$ Significantly different from control value.

two populations of calmodulin binding sites: a higher-affinity binding site with a dissociation constant $\left(K_{\mathrm{D}}\right)$ of $1.3 \times 10^{-7} \mathrm{M}$ and a lower-affinity binding site with a $K_{\mathrm{D}}$ of $2.9 \times 10^{-7} \mathrm{M}$ (TABLE 5 ). When the calmodulin binding curve was evaluated by Hill analysis ${ }^{21}$ to determine whether there were cooperative interactions among the binding sites, a linear Hill plot with a coefficient of $0.90 \pm 0.14(95 \%$ confidence limit] was obtained. This may suggest that there is no appreciable cooperativity among calmodulin binding sites.

The effect of trifluoperazine $\left(10^{-4} \mathrm{M}\right)$ on calmodulin binding was also analyzed by the Scatchard method. The analysis revealed that the higher-affinity

TABLE 5

EFFect of $10^{-4} \mathrm{M}$ Trifluoperazine on $\left[{ }^{125}\right.$ I]CALMOdulin Binding in Rat Striatal Membranes*

\begin{tabular}{lll}
\hline & \multicolumn{1}{c}{ Control $(11)^{\dagger}$} & $+10^{-4} \mathrm{M}$ Trifluoperazine (5) $\dagger$ \\
\hline Higher affinity binding & & \\
Number of sites & $8.5 \pm 0.8 \mathrm{pmol} / \mathrm{mg}$ protein & $\begin{array}{l}3.3 \pm 0.4 \mathrm{pmol} / \mathrm{mg} \text { protein } \ddagger \\
1.4 \times 10^{-7} \mathrm{M}\end{array}$ \\
App. $K_{\mathrm{D}}$ & $1.3 \times 10^{-7} \mathrm{M}$ & \\
Lower affinity binding & & $13.3 \pm 1.5 \mathrm{pmol} / \mathrm{mg}$ protein \\
Number of sites & $11.8+1.2 \mathrm{pmol} / \mathrm{mg}$ protein & $13 \times 10^{-6} \mathrm{M} \ddagger$ \\
App. $K_{\mathrm{D}}$ & $2.9 \times 10^{-7} \mathrm{M}$ & $1.3 \times$ \\
\hline \hline
\end{tabular}

${ }^{*}$ All values were determined from Scatchard plot.

† Number of experiments.

$\ddagger$ Significantly different from control values $(\mathrm{P}<0.05)$. 
binding component for calmodulin was significantly inhibited by trifluoperazine $\left(10^{-4} \mathrm{M}\right)$, while the $K_{\mathrm{D}}$ for lower-affinity binding component was increased (TABLE 5).

\section{Alterations in Calmodulin Content During Supersensitivity to Catecholamines in Brain}

We have shown previously that calmodulin content was increased in rat striatal membranes after chronic treatment with cataleptogenic antipsychotic drugs. ${ }^{5}$ Furthermore, Lucchelli et al. ${ }^{22}$ have shown increases in striatal content of calmodulin in rat striatum after hemisection, indicating that increases in calmodulin will occur after supersensitivity to dopamine is produced by a variety of means. We wished to investigate whether other dopaminergic areas, such as the hypothalamus and the limbic system, had increased calmodulin content as well. The calmodulin content was measured in the membranes $(27,000 \times \mathrm{g}$ fraction $)$ of

TABLE 6

Calmodulin Concentration in Membranes of Several Brain Areas from Rats Treated Chronically with Saline and Haloperidol*

\begin{tabular}{lrcc}
\hline \hline & & \multicolumn{2}{c}{ Calmodulin } \\
\cline { 4 - 4 } \multicolumn{1}{c}{ Area } & $N$ & & $\begin{array}{c}\text { Saline } \\
(\mu \mathrm{g} / \mathrm{mg} \text { membrane protein } \pm \text { S.E.M. })\end{array}$ \\
\hline Striatum & 8 & $4.0 \pm 0.2$ & $5.1 \pm 0.1 \dagger$ \\
Hypothalamus & 13 & $3.5 \pm 0.2$ & $2.9 \pm 0.2 \ddagger$ \\
Nucleus Accumbens & 5 & $3.3 \pm 0.1$ & $3.2 \pm 0.1$ \\
\hline \hline
\end{tabular}

${ }^{*}$ Male Sprague Dawley rats were injected daily for 20 days with $2.5 \mu \mathrm{mol} / \mathrm{kg}$ (s.c.) haloperidol or $0.1 \mathrm{ml}$ saline. One week after stopping chronic injections the rats were sacrificed and calmodulin content was measured as described in METHODS.

$\dagger P<0.05$ as compared to value for saline-treated animals.

$\ddagger P<0.001$ as compared to value for saline-treated animals.

the hypothalamus and nucleus accumbens after chronic haloperiodol treatment in rats. The rats were treated as described in TABLE 6 . As TABLE 6 illustrates, the only area showing an increase in membrane calmodulin after chronic haloperidol treatment was the striatum. A decrease in calmodulin was found in the membrane fraction of the hypothalamus but the change was quite small. At the present time the significance of this is obscure.

The ability of calmodulin content to be altered under conditions of noradrenergic supersensitivity was examined. Treatment of rats with reserpine ${ }^{23}$ or 6-hydroxydopamine $\mathrm{e}^{24}$ (6-OHDA) can result in supersensitivity of noradrenergic receptors in the cerebral cortex. In order to examine whether calmodulin could be involved in modulating NE responses in the brain, supersensitivity to NE was developed by these methods. One group of rats was treated with reserpine $(2.5$ $\mathrm{mg} / \mathrm{kg}$ i.p.J for four days and sacrificed 4 hours later. The calmodulin content in the membranes $[27,000 \times g$ fraction $)$ of the cerebral cortex was measured. In another experiment rats were injected intraventricularly on two successive days with 6-OHDA $(200 \mu \mathrm{g})$ as described by Kalisker et al. ${ }^{24}$ Two weeks later the animals were sacrificed and calmodulin was measured in the membrane 
fractions $[27,000 \times \mathrm{g}]$ from the cerebral cortex and striatum. The results are shown in TABLE 7 . The calmodulin content did not change in the cerebral cortex of rats subjected to either drug treatment. The calmodulin content was, however, significantly increased in the striatal membranes of 6-OHDA rats. This is not too surprising since intraventricularly administered 6-OHDA can cause extensive depopulation in the zona compacta of the substantia nigra. Although NEsensitive adenylate cyclase activity was not measured, the appearance of noradrenergic supersensitivity in the cortex after these treatments is well documented.

\section{DisCUSSION}

The participation of calcium in catecholamine-stimulated adenylate cyclase activity in the brain is not well understood. Calcium has generally been consid-

TABLE 7

Calmodulin Content in Membranes of Rat Cerebral Cortex and Striatum AFTER 6-OHDA OR RESERPINE TREATMENT

\begin{tabular}{cccc}
\hline \hline & & \multicolumn{2}{c}{ Calmodulin Concentration } \\
\cline { 3 - 3 } Treatment & \multicolumn{2}{c}{$\begin{array}{c}\text { Striatum } \\
\text { ( } \mu \mathrm{g} / \mathrm{mg} \text { protein } \pm \text { S.E.M.) }\end{array}$} \\
\hline Saline $(5)$ & $5.0 \pm 0.2$ & $5.2 \pm 0.2$ \\
6-OHDA $(5)^{\star}$ & $6.2 \pm 0.1 \neq$ & $5.5 \pm 0.4$ \\
Saline $(8)$ & - & $5.0 \pm 0.3$ \\
Reserpine (8) & - & $5.1 \pm 0.3$ \\
\hline
\end{tabular}

*6-OHDA-treated rats were injecled intraventricularly using stereotoxic coordinates with $200 \mu \mathrm{g}$ of 6-OHDA on each of 2 successive days. Animals were sacrificed 2 weeks after last injection.

† Reserpine-treated rats were treated daily with reserpine $(2.5 \mathrm{mg} / \mathrm{kg}$ i.p. $)$ for 4 days and sacrificed 4 hours after last injection. Number of animals is given in parentheses.

$\ddagger \mathrm{P}<0.001$ when compared to value for saline-treated animals.

ered to be inhibitory to DA-sensitive adenylate cyclase activity in the striatum because stimulation in homogenates can only be detected in the presence of EGTA, a calcium chelating agent. This effect occurred because EGTA decreased basal adenylate cyclase activity and permitted expression of DA sensitivity. ${ }^{25}$ In other systems, however, calcium has been shown to enhance catecholamine stimulation of cyclic AMP production. For example, extracellular calcium is required for the increased production of cyclic AMP by $\alpha$-adrenergic agonists in cerebral cortical slices ${ }^{26} \mathrm{~A}$ stronger role for a stimulatory effect of intracellular calcium in NE-stimulation of cyclic AMP production was shown by Brostrom et $\mathrm{al}^{27}$ using $\mathrm{C} 6$ glioma cells. The ability of $\mathrm{C} 6$ glioma cells to accumulate cyclic AMP in response to NE was reduced $60-70 \%$ following nearly total calcium depletion of the cells in culture by EGTA.

Since calmodulin is so integrally involved with the effects of calcium on cyclic nucleotide metabolism in the brain, one cannot properly determine the effects of calcium without consideration of calmodulin. Calmodulin is present in brain membranes and is enriched in synaptic membranes. ${ }^{2}$ Therefore, we 
studied the effects of calcium and calmodulin on basal and DA-stimulated adenylate cyclase activity in calcium and calmodulin depleted rat striatal membranes.

We found that calmodulin stimulated basal adenylate cyclase activity in a biphasic manner that was dependent upon the concentration of calcium. Stimulation of adenylate cyclase by calmodulin was maximal at an effective calcium concentration of $0.14 \mu \mathrm{M}$ which is within resting levels of calcium in nerve membranes. ${ }^{2 \boldsymbol{B}}$ Calcium and calmodulin inhibited adenylate cyclase activity at higher concentrations of calcium. The effects of calmodulin on basal adenylate cyclase activity would conceivably depend on calcium flux in the membrane. At resting levels of calcium, adenylate cyclase activity would be increased by calmodulin but as calcium levels rise the system would become inhibited.

DA sensitivity was abolished in calcium and calmodulin-depleted membranes and could not be restored by addition of either agent. A dose dependent stimulation of adenylate cyclase by DA was found only when guanyl nucleotides were included in the assay at concentrations of at least $10 \mu \mathrm{M}$. Similar results were found by Sulakhe et al $^{29}$ Addition of $125 \mu \mathrm{M}$ calcium inhibited DA-stimulated adenylate cyclase activity in the presence of either guanyl nucleotide. When calmodulin was present, however, the maximal velocity of the reaction was somewhat restored and the sensitivity to DA was increased. Thus calmodulin affected both the $K_{a}$ for DA and $V_{\max }$ of the DA-sensitive adenylate cyclase activity. This suggests that at physiological, resting concentrations of calcium, DA will not greatly stimulate adenylate cyclase activity unless calmodulin is present.

The exact molecular mechanism in which calmodulin affects DA-sensitive adenylate cyclase activity is not yet known. Calmodulin could be simply acting as a calcium scavenger, preventing it from inhibiting DA-sensitive adenylate cyclase. There are several findings that do not support this explanation. First, calmodulin actually stimulated basal adenylate cyclase activity in the presence of calcium. Calcium alone had little effect on basal adenylate cyclase activity until very high concentrations. Second, troponin $\mathrm{C}$, a calcium-binding protein with some sequence homology to calmodulin and a similar molecular weight, did not mimic the action of calmodulin on basal or DA-stimulated adenylate cyclase activity, even at concentrations ten times that of calmodulin. Troponin $\mathrm{C}$ actually binds calcium with an affinity similar to that of calmodulin. Third, we have shown that under conditions used in this assay, $\left.{ }^{[25} \mathrm{I}\right] \mathrm{calmodulin}$ will bind to the striatal membranes in a calcium-dependent manner. The binding was specific for calmodulin and was inhibited by trifluoperazine, an antipsychotic drug known to bind calmodulin. We found that there were at least two classes of binding sites for calmodulin in the membranes. The fact that trifluoperazine mainly affected the higher affinity binding site suggests that this site in the striatum could play an important role in mediating the action of trifluoperazine.

It is highly likely that there is an interaction between calcium, calmodulin, and the guanyl nucleotide binding protein in brain membranes. Wescott et al. ${ }^{10}$ found that a guanyl nucleotide-sensitive fraction was required for calmodulin stimulation in a purified calmodulin-dependent adenylate cyclase preparation from cerebral cortex. We found, as have others, ${ }^{29}$ that both GTP and Gpp(NH)p stimulated basal adenylate cyclase activity in our membrane preparation and were required for DA stimulation. The effects of guanyl nucleotides on basal and DA-stimulated adenylate cyclase activity are variable and may depend on the type of membrane or homogenate preparation. ${ }^{30}$ In our preparation, $\mathrm{Gpp}(\mathrm{NH}) \mathrm{p}$ stimulation of adenylate cyclase activity was much more sensitive to calcium 
inhibition than was GTP stimulation. Calcium, did, however, decrease DA stimulation of adenylate cyclase activity in the presence of both Gpp(NH)p and GTP. The molecular association induced by $\mathrm{Gpp}(\mathrm{NH}) \mathrm{p}$ in striatal membranes may be similar to that achieved in the presence of GTP and hormone. In this respect the role of guanyl nucleotides in dopamine receptor activation could parallel their mechanism of activation of the $\beta$-adrenergic receptor in erythrocytes. ${ }^{31}$ Our data suggest that it is this association or "activation state" achieved by $\mathrm{Gpp}(\mathrm{NH}) \mathrm{p}$ or DA that can be inhibited by calcium and with which calmodulin can interact.

Our present findings correlate with our previous work concerning the relationship between calmodulin and dopaminergic supersensitivity in rat striatum. ${ }^{5.32}$ Animals chronically treated with antipsychotic drugs had increased calmodulin content in their striatal membranes. The adenylate cyclase in the striatal membranes of the drug-Ireated animals showed an increased sensitivity to DA as shown by a 3-fold decrease in the apparent $K_{\mathrm{a}}$ for DA. This further supports a role for calmodulin in dopaminergic activity and even supersensitivity to DA in the rat striatum.

Our results indicate that calmodulin is mainly important for dopaminergic supersensitivity in the striatum, although we did not do experiments validating that there was dopaminergic supersensitivity occurring in the other areas. The strong change of calmodulin seen in the striatum may be due to the feedback regulation mechanism of the nigrostriatal system. The difference in regulation of the striatal receptors could account for these results. Similarly, the amount of calmodulin did not change a membrane fraction from the cerebral cortex of rats made supersensitive to NE. There is evidence that calmodulin is important for adrenergic stimulation of cyclic AMP in the brain ${ }^{27.33}$ so its possible participation in adrenergic supersensitivity may occur in a more subtle manner. We can conclude that in rat striatum, during normal synaptic activity or under conditions of greatly altered synaptic input, calmodulin could be vital in attempting to maintain normal dopaminergic: function through stimulatory and inhibitory effects.

\section{ACKNOWLEDGMENTS}

We would like to thank Joe Romson for helping with the drug treatment studies. We are grateful to Dr. James D. Potter, Department of Pharmacology, University of Cincinnati for graciously supplying us with troponin C.

\section{REFERENCES}

1. Cheung, W. Y. 1980. Calmodulin plays a pivotal role in cellular regulation. Science 207: 19-27.

2. GneGy. M. E.. J. A. NATHANSON \& P. Uzunov. 1977. Release of the phosphodiesterase activator by cyclic AMP-dependent ATP: protein phosphotransferase from subcellular fractions of rat brain. Biochim. Biophys. Acta 497: 75-85.

3. Wood, I. G., R. W. Wallace, ]. N Whitaker \& W. Y. Cheung. 1980. Immunocytochemical localization of calmodulin and a heat-labile calmodulin-binding protein (CaM-BP ${ }_{\text {80 }}$ ) in basal ganglia of mouse brain. ]. Cell Biol. 84: 66-76.

4. GRAB, D. I., K. BERZINS, R. S. COHEN \& P. SteKEVITZ, 1979. Presence of calmodulin in postsynaptic densities isolated from canine cerebral cortex. J. Biol. Chem. 254: 86908696 . 
5. Gnegy, M. E., P. Uzunov \& E. CostA. 1976. Regulation of dopamine stimulation of striatal adenylate cyclase by an endogenous $\mathrm{Ca}^{++}$-binding protein. Proc. Natl. Acad. Sci. USA 73: 3887-3890.

6. Gnegy, M., P. Uzunov \& E. Costa. 1977. Participation of an endogenous $\mathrm{Ca}^{++}$-binding protein activator in the development of drug-induced supersensitivity of striatal dopamine receptors. J. Pharm. Exptl. Therap. 202: 558-564.

7. GNEGY, M. E. \& Y. S. LAU. 1980. Effects of chronic and acute treatment of antipsychotic drugs on calmodulin release from rat striatal membranes. Neuropharmacology 19: 319-323.

8. Teshima, Y. \& S. KaKiUChi. 1978. Membrane-bound forms of $\mathrm{Ca}^{+2}$-dependent protein modulator: $\mathrm{Ca}^{+2}$-dependent and independent binding of modulator protein to the particulate fraction from rat brain. J. Cyclic Nucleotide Res. 4: 219-231.

9. KLEE, C. B. \& M. H. KrinKs. 1978. Purification of cyclic $3^{\prime}, 5^{\prime}$-nucleotide phosphodiesterase inhibitory protein by affinity chromatography on activator protein coupled to Sepharose. Biochemistry 17: 120-126.

10. WESCOTT, K. R., D. C. LAPORTE \& D. R. STORM. 1979. Resolution of adenylate cyclase sensitive and insensitive to $\mathrm{Ca}^{++}$and calcium-dependent regulatory protein (CDR) by CDR-Sepharose affinity chromatography. Proc. Natl. Acad. Sci. USA 76: 204208.

11. Vandermeers, A., P. Robberecht, M.-C. Vandermeers-Piret, J. Rathe \& I. ChrisTOPHE. 1978. Specific binding of the calcium-dependent regulator protein to brain membranes from the guinea pig. Biochem. Biophys. Res. Commun. 84: 1076-1081.

12. LEVIN, R. M. \& B. WEIss. 1977. Binding of trifluoperazine to the calcium-dependent activator of cyclic nucleotide phosphodiesterase. Molec. Pharmacol. 13: 690-697.

13. Brostrom, M. A., C. O. Brostrom \& D. J. WolfF. 1978. Calcium-dependent adenylate cyclase from rat cerebral cortex: activation by guanine nucleotides. Arch. Biochem. Biophys. 191: 341-350.

14. KLEE, C. B. 1977. Conformation transition accompanying the binding of $\mathrm{Ca}^{++}$to the protein activator of $3^{\prime}, 5^{\prime}$-adenosine monophosphate phosphodiesterase. Biochemistry 16: $1017-1024$.

15. KrishnA, G., B. Weiss \& B. B. Brodie. 1968. A simple sensitive method for the assay of adenyl cyclase. J. Pharmac. Exptl. Therap. 163: 379-385.

16. Chafouleas, J. G., J. R. Dedman, R. P. Munjaal \& A. R. Means. 1979. Calmodulin. Development and application of a sensitive radioimmunoassay. J. Biol. Chem. 254: 10262-10267.

17. SCHMIDT, W. K. \& E. L. WAY. 1979. Direct assay for calcium in brain homogenates and synaptosomal pellets. J. Neurochemistry 32: 1095-1098.

18. Lowry, O. H., N. J. Rosebrough, A. L. FarR \& R. J. Randall. 1951. Protein measurement with the Folin phenol reagent. J. Biol. Chem. 193: 265-275.

19. NANNINGA, B. \& R. KEMPEN. 1971. Role of magnesium and calcium in the first and second contraction of glycerin-extracted muscle fibers. Biochemistry 10: 2449-2456.

20. Stevens, F. C., M. Walsh, H. C. Ho, T. S. Teo \& J. H. Wang. 1976. Comparison of calcium-binding proteins. Bovine heart and brain protein activators of cyclic nucleotide phosphodiesterase and rabbit skeletal muscle troponin C. J. Biol. Chem. 251: 4495-4500.

21. HILL, A. V. 1910. The possible effects of aggregation of the molecular of haemoglobin on its dissociation curves. J. Physiol. 40: iv-vii.

22. Lucchej.Li, A., A. GuidotTi \& E. Costa. 1978. Striatal content of a $\mathrm{Ca}^{++}$-dependent regulator protein and dopaminergic receptor function. Brain Res. 155: 130-135.

23. Palmer, G. C., H. R. WAGNer \& R. W. Putnam. 1976. Neuronal localization of the enhanced adenylate cyclase responsiveness to catecholamines in the rat cerebral cortex following reserpine injections. Neuropharmacol. 15: 695-702.

24. Kalisker, A., C. O. Rutledge \& J. P. Perkins. 1973. Effect of nerve degenerations by 6-hydroxydopamine on catecholamine-stimulated adenosine $3^{\prime}, 5^{\prime}$-monophosphate formation in rat cerebral cortex. Molec. Pharmacol. 9: 619-629.

25. Clement-Cormier, Y. C., R. G. Parrish, G. L. Petzold, J. W. Kebabian \& P. GREENGARD. 1975. Characterization of a dopamine-sensitive adenylate cyclase in rat caudate nucleus. J. Neurochem. 25: 143-149. 
26. Schwabe, U., Y. OHGa \& J. W. Daly, 1978. The role of calcium in the regulation of cyclic nucleotide levels in brain slices of rat and guinea pig. Naunyn-Schmied. Arch. Pharmacol. 302: 141-151.

27. Brostrom, M. A., C. O. Bros'rrom \& D. J. WolfF. 1979. Calcium dependence of hormone-stimulated cAMP accumulation in intact glial tumor cells. J. Biol. Chem. 254: $7548-7557$.

28. KRETSINGER, R. H. 1979. The informational role of calcium in the cytosol. Adv. Cyclic Nucleotide Res. 11: 1-26.

29. Sulakhe, P. V., N. L. Leung, A T. Arbus, S. J. Sulakhe, S.-H. Jan \& N. Narayaran. 1977. Catecholamine-sensitive adenylate cyclase of caudate nucleus and cerebral cortex: Effects of guanine nucleotides. Biochem. J. 164: 67-74.

30. Roufogalis, B. D., M. Thornton \& D. N. WADE. 1976. Nucleotide requirement of dopamine sensitive adenylate cyclase in synaptosomal membranes from the straitum of rat brain. J. Neurochem. 27: 1533-1535.

31. LimBiRD, L. E., D. M. GiLl \& R. J. LefKowitz. 1980. Agonist-promoted coupling of the $\beta$-adrenergic receptor with the guanine nucleotide regulatory protein of the adenylate cyclase system. Proc. Natl. Acad. Sci. USA 77: 775-779.

32. GNEGY, M. E., A. LuCCHELli \& E. COSTA. 1977. Correlation between drug-induced supersensitivity of dopamine dependent striatal mechanisms and the increase in striatal content of the $\mathrm{Ca}^{++}$-regulated protein activator of cAMP phosphodiesterase. Naunyn-Schmied. Arch. Pharmacol. 301: 121-127.

33. GNEGy, M. E., T. Hultin \& G. TReisman. 1980. Effect of calmodulin on catecholaminelinked adenylate cyclase in rat striatum and cerebral cortex. Adv. Biochemical Psychopharmacology 21: 125-131.

\section{Discussion of THE PAPER}

DR. D. FlockHaRT (Vanderbilt University, Nashville, TN): Do you consider it possible that your two calmodulin affinities are actually due to two different populations of iodonated calmodulin?

DR. N. GNEGY: We put iodonated calmodulin over gels. It seems to be a pure species.

DR. FlOCKHART: Yes, but, you can have a mono-, di- or tri-iodonated calmodulin which would have altered it.

DR. GNEGY: Well, our stoichiometry doesn't seem to support that but it is always possible.

Dr. WOLFe (National Institutes of Health, Bethesda, MD): If the calmodulin interacts with the $G$ subunit you should be able to affect ATP ribosylation with cholera toxin and NAD. Have you tried such experiments?

Dr. GNEGY: No. But I think due to the experiments of Moss and Vaughn I would say it seems a very likely possibility because they showed that calmodulin can affect cholera toxin action in the brain. Another thing I had to take into account going along with the work shown by the Brostroms is that there could be two forms of cyclase in the membrane, one calcium sensitive, one not, and one may be inhibited by calcium and the other stimulated. So, what I may be looking at is an interplay between the two. 